\title{
Os passeios invisíveis do conceito do corpo no Japão
}

\author{
Viviana de Souza Collety
}

\section{GREINER, Christine.}

Cultura Pop. Leituras do corpo no Japão e suas diásporas cognitivas. São Paulo: N-1 Edições, 222 p., 2015.

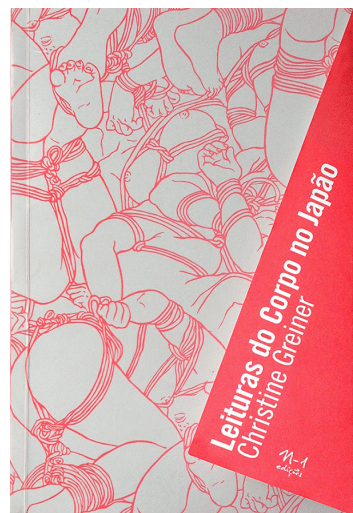

Resumo: À luz de disciplinas como a semiótica, ciências da cognição, filosofia, sociologia e arte, o conceito do corpo no Japão é aqui revisitado em toda a sua complexidade. Para acompanhar o instável passeio cognitivo do corpo no Japão, Christine Greiner aponta sua lupa sensível e política para episódios cruciais da história japonesa, desde a pré-história até o momento atual. A partir de um longo e vigoroso percurso de pesquisa em torno das transformações e implicações dos conceitos do corpo no oriente e no ocidente, a pesquisadora revela a amplitude da questão.

Palavras-chave: corpo no Japão; semiótica; ciências da cognição; arte e corpo.

Abstract: The invisible promenade of the concept of the body in Japan - Under the light of disciplines like semiotics, cognitive science, philosophy, sociology and art, the concept of the body in Japan is re-visited here in all its complexity. To accompany the unstable cognitive walk of the body in Japan, Christine Greiner points her sensible and politics lens over some key moments of the Japanese history, from the prehistory to the current moment. After a long and responsable inquiry around the transformations and implications of the body's concept between east and west, the author reveals the amplitude of the questions concerning the body.

Key words: body in Japan; semiotics; cognitive science; art and body. 
Coerente com uma rica trajetória de quase vinte anos de pesquisa 'trans', 'inter' ou ainda 'in' disciplinar em torno das múltiplas visões do corpo, do Japão e das conexões entre 'oriente' e 'ocidente', Christine Greiner publica suas últimas Leituras do corpo no Japão e suas diásporas cognitvas, pela $n$-1 edições em 2015.

O livro flui em cadência ritmada com a inspiração da autora, que inicia cada capítulo com trechos de notas de viagem. Parece não haver distinção entre a respiração e a inspiração, criativa e profundamente política da autora. O corpo de quem escreve está presente, como não poderia deixar de ser, e o próprio livro é um exemplo de que percepções caminham junto com cognição, e o conhecimento se dá por meio dessas conexões.

Sem abandonar o rigor científico e as características dinâmicas de uma formação em jornalismo, a autora revela caminhos e encruzilhadas de um longo percurso de pesquisa, com entrevistas, viagens, aulas, reflexões e trocas, que possibilitaram suas leituras cruzadas entre história, política, estética, filosofia, ciências da cognição e arte. Ela mapeia momentos-chaves da história do corpo no Japão, pinçados em função de uma escolha metodológica que cruza bibliografias coletadas durante os vários anos de pesquisa.

Desde a pré-história até o momento atual, Greiner revela um Japão singular e muitas vezes inesperado, alinhavando associações que transitam da tradicional medicina chinesa à recente explosão dos salões de beleza, passando pelas reinvenções do corpo no estado nacional e no pós-guerra. Concepções do corpo que habitam o Japão do nosso imaginário - dos samurais às garotas de Tokyo -, ganham complexidade e tensionam com a ideia de que, ali, "o humano não esta apartado nem é superior a nada", destacando, a partir de lupas políticas e estéticas, "a aliança indissolúvel entre natureza e cultura que norteia as concepções de corpo no Japão até hoje" (GREINER, 2015, p. 24).

Entre as notas que iniciam cada capítulo, a partir do pequeno apartamento abarrotado de livros no centro de São Paulo vemos surgir as colinas de Kyoto e somos transportados ao metrô em Tokyo. Nada foge à lupa sensível e política da autora, pois nada está separado quando o corpo é reconhecido como o centro dos processos cognitivos. Dialogando com autores como Mark Johnson, William James, Charles Sanders Peirce, Kuryiama Shigehiza e Uno Kuniichi, entre outros, Greiner evidencia como tal reconhecimento fez implodir uma série de estereótipos e subverteu linhas de distinção entre oriente e ocidente (GREINER, 2015, p. 187).

Do Japão dos corpos em fluxo com os ventos, do século XV a. C. - sistema teórico desenvolvido a partir da medicina chinesa (GREINER, 2015, p.26) -, passando pelo corpo do ser para a vida da proposta mesológica de Watsuji Tetsuro (GREINER, 2015, p.50), vamos identificando interferências ao construir e desconstruir conceitos e concretudes do corpo.

Em um fluxo de pensamento responsável por costurar epistemologias, Greiner tece uma reflexão sobre as implicações políticas do corpo soberano das eras medievais do Japão ao período Edo (ou Tokugawa), dialogando com Agamben e as manifestações de práticas de resistência ao estigma do estado e corpo nacional. Após a segunda guerra, a imagem do imperador Hiroito é associada à derrota japonesa e toma um papel importante nas transformações subsequentes: o corpo antes inacessível do soberano tem sua fragilidade confundida com as ruínas da guerra. 
Entretanto, como o conceito do corpo continua a deslocar-se por entre as redes cognitivas, percebe-se que é no fato de tudo acabar incessantemente que tudo continua (GREINER, 2015, p. 49). Do corpo fragilizado do pós-guerra, passando pelos esforços em reconstruir as ruínas com as olimpíadas sediadas no Japão em 1964, chegamos ao século XX, em um Japão dos fanstasmas fora da máquina (GREINER, 2015, p. 159). Saúde, disciplina e bem-estar dão lugar à aparência. Em 1990, as redes capitalistas estão bem instaladas e o Japão ocupa o segundo lugar no ranking mundial da indústria de cosméticos. A ênfase na pesquisa militar é substituída pelos eletrônicos e a onda do comércio marca os corpos, instaurando novas formas de se relacionar com a estética.

No entanto, quando se trata da produção de subjetividades, a autora sinaliza a importância de não cair em determinismos que diagnosticam ideias e modos de vida em função do consumo e sistemas de poder (GREINER, 2015, p. 167). Nesse sentido, metáforas como a do vento, explorada no primeiro capítulo do livro, ajudam a compreender que, no Japão, a relação entre corpo e mente nunca foi reduzida à inserção de uma substância não-extensa dentro de um corpo com forma limitada. Os fantasmas estão fora das máquinas e isso interfere nos modos de vida.

Nos anos antes e pós-guerra, três artistas japoneses são destacados, evidenciando dinâmicas de resistência operadas pelas artes e novos circuitos mediáticos. Okamoto Taro, Hijikata Tatsumi e Murakami Takashi propuseram formas de arte engajadas em uma busca por outras formas de pensar a vida ao problematizar as novas relações com o mercado, o estado político do corpo e uma desierarquização de padrões estéticos.

Durante os capítulos, as reconfigurações do conceito do corpo articulam uma trama que complexifica e localiza o corpo em seu estado político, poético e mediático. Assim, texturas cognitivas e epistemológicas vão se estabelecendo e "materializando o saber", como coloca a autora (GREINER, 2015, p.43).

Traduções e trânsitos do conceito de corpo têm instigado a pesquisadora ao longo de toda a sua trajetória. Para citar outros dois exemplos desse vasto mapeamento realizado por Greiner, entre referências, indagações e uma cartografia do percurso do conceito e representação do corpo pelo mundo, citamos ainda: O corpo, pistas para estudos indisciplinares (2005) e O corpo em crise, novas pistas e o curto-circuito das representações (2010), dentre uma vasta lista de publicações que abrangem aindatemas como dança, arte, moda e processos de comunicação.

Viviana Coletty é doutoranda pela escola doutoral EDESTA em cotutela com a PUC-SP e pesquisadora pela Labex/ Equipe de pesquisa Cenas do mundo, criação e saberes críticos, Universidade Paris 8.

vivianascoletty@gmail.com 